\title{
内科プライマリ・ケア医の知っておきたい “ミニマム知識” リウマチ性疾患が疑われた時の身体所見・検㚗所見の見方
}

高橋 裕一

Key words : 関節痛, Raynaud現象, 不明熱

〔日内会誌 $97: 2587 \sim 2589,2008 〕$

はじめに

リウマチ膠原病の診断過程は病歴聴取(問診), 身体所見，検查所見により総合的に行われ，専 門的な技術は要しないことがほとんどです。そ こで内科一般診療において,しばしば遭遇する, こわばり・関節痛, Raynaud現象, 発熱を主訴と した患者でリウマチ膠原病の診断に結びつく身 体所見・検査所見について述べます.

\section{こわばり・関節痛}

こわばりを主訴とした患者では, 手指, 手関 節をみることが大切です．手指で腫れている関 節はないか, 腫れている関節の部位はどこか注 意して触診します.まず手指の遠位指節間 (DIP) 関節の結節性腫大（Heberden結節）がみられる 場合は変形性関節症 $(\mathrm{OA})$ と診断してほぼ間違 いありません. DIP関節が角のように突出し, 硬 く触れます。また近位指節間 (PIP) 関節の結節 性腫大 (Bouchard結節) がみられることもあり ます．この場合職業歴を聞くことが重要です. 例えば縫製業, 飲食業等で手をよく使う仕事を する人はOAになる頻度が高いです，手指のOA の場合, 必ずしも専門医への紹介は必要なく,

たかはし ゆういち：ゆうファミリークリニック
安静や局所保温の生活指導で経過をみます。一

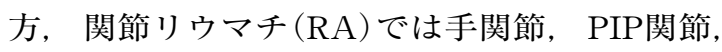
中手指節間 $(\mathrm{MP})$ 関節の腫脹が多くの例でみら れます. RAでの腫脹関節は触診上, 関節水腫が あるため軟らかく，ブヨブヨした感じで触れま す.この腫脹関節の部位や触診所見の違いで, おおむね手指のOAと鑑別ができます。その他, 早期のRAで見逃してはいけない関節として, 中 足趾節（MTP）関節があります．患者の足趾の 付け根の痛みや足の裏のゴッゴッ感, 足底の違 和感としての訴えに注意しましょう。これら症 状が確認されたら, リウマトイド因子を測定し ます. リウマトイド因子は従来の定量, 半定量 法 (RF定量, RAPA) の他, 抗ガラクトース欠 損IgG抗体が知られています. 現在は抗環状シト ルリン化ペプチド抗体(抗CCP抗体)が, 感度, 特異度とも優れているとされていて, 早期RA には有用です. RAの疾患活動性の判定として赤 沈, CRP(C-reactive protein), 血算, 血清蛋白 も測定します.またRA以外の他の膠原病でも関 節痛を訴えることが多く, 抗核抗体もスクリー ニング検査に入れておきましょう. RAの診断が 確からしい場合は, 一度専門医へ紹介し, 活動 性の評価, 治療方針をたててもらうのがよいで しょう. 現在メトトレキサートがアンカードラッ グとして使用されつつあること, さらに生物学 的製郕の導入により早期RAは骨破壊をきたさず 寛解維持できる時代となりました。 そのために 
も早期診断, 早期治療が重要です.

逆に検診等で明らかとなったリウマトイド因 子陽性の結果を患者に相談された場合は, こわ ばり・関節痛の有無を問診し, 手指・手関節等 関節の触診を行い, 異常がなければ経過観察で よいでしょう。

その他，まれな関節炎として注意すべき疾患 は, 乾癬性関節炎, 強直性脊椎炎, 掌蹠膿疮症 性骨関節炎, パルボウイルスB19 感染症などが挙 げられます。乾癄性関節炎, 掌蹠膿疮症性関節 炎では特徵的な皮膚病変がみられ, 強直性脊椎 炎では男性に多いこと, 脊柱の痛みがあるかな ど注意深い診察や問診で鑑別ができます。パル ボウイルス感染症での関節炎の診断への手がか りは, 家族内や接触者にパルボウイルス感染 (り んご病）の人がいないかの問診が重要です.

\section{Raynaud現象}

Raynaud現象をきたす疾患としては, 原因不明 なものをRaynaud病, 原因が判明しているものを Raynaud症候群と言います. Raynaud病の場合は 左右対称に手指の色調の変化が出現しますが,

Raynaud症候群では $1 ， 2$ 本の指に起こることが あります. Raynaud症候群の原因は膠原病である ことが多く, そのほか慢性動脈閉塞やチェーン ソーを使った仕事をしていた人の振動病が含ま れます.実際にRaynaud現象かどうかを診断する 方法として, 指尖脈波やサーモグラフィーが有 用ですが, 設備上の問題もあるので, 日常診療 では実際冷水に手を入れてもらい, 手指の色調 の変化が出現するかどうか確認する（冷水誘発 試験）のが簡便な方法です，典型的な色調の変 化としては, 蒼白 $\rightarrow$ 暗紫色 $\rightarrow$ 発赤の順に変色し てゆきます．もうひとつ手指の所見として，紡 錘状に腫脹があるかどうかは重要な所見です. さらに皮䖉の硬さも実際指で掴めるかどうか確 認してみます。紡錘状の腫脹は混合性結合組織 病（MCTD）でよくみられます。指で掴めない
皮膚硬化は全身性硬化症（強皮症）が強く疑わ れます。また手指伸側PIP関節，MP関節付近に 落屑を伴う皮疹がみられた場合は皮膚筋炎が疑 われます。これらの所見を参考に抗核抗体を検 查します。一般的には, 抗核抗体が 160 倍以上 の陽性であれば有意であると判断されます。さ らに各々の疾患の標識抗体として, 抗DNA抗体, 抗RNP抗体, 抗SS-A抗体, 抗SS-B抗体. 抗Scl70 抗体等を追加して調べます. その他全身症状 として, リンパ節や耳下腺の腫脹 (Sjögren症候 群), 息切れの自覚症状, 胸部X線写真での間質 性肺炎(肺線維症), 心電図や心エコーでの右心 負荷(肺高血圧)の所見 (全身性硬化症, MCTD), 胸焼け（逆流性食道炎の存在) (MCTD, 全身性 硬化症)の有無がないか注意しましょう. Raynaud 現象のみの症状で検查上, 抗核抗体等㓌性であ り膠原病の可能性が低い場合は, 生活指導や血 管拡張薬の投与で様子をみて構いません. 一方 抗核抗体陽性で, 膠原病が疑われた場合は, 確 定診断，治療方針の決定の目的で専門医への紹 介が望ましいです。

\section{発熱}

一般診療において発熱を呈する疾患の原因の ほとんどは，急性の感染性疾患です。しかし診 断がつかないまま発熱が継続し，患者が不安に なる場合もしばしばあります。そこで不明熱の 原因となりうる非感染性疾患の代表的なものを いくつか紹介します.

膠原病のなかで発熱を主症状とする疾患とし ては, 成人発症Still病と血管炎症候群が挙げられ ます. 成人発症Still病の発熱の特徵は $38^{\circ} \mathrm{C}$ 以上 の弛張熱を呈します。またサーモンピンク様の 皮疹が特徴的とされています．検査では特異的 な検查所見はありませんが, CRP高值や赤沈の 高度六進, 白血球増加, 肝機能障害, フェリチ ンの著増（正常上限の 5 倍以上）がほとんどの 症例でみられます。血小板や他の血球減少がみ 
られた場合は血球貪食症候群の合併の可能性が あり注意を要します。血管炎症候群でも発熱は ほとんどの症例でみられます。身体症状として は, 多関節痛, 筋痛, 皮疹・皮下結節, シビレ 等の末梢神経障害を呈します.突如神経麻痺(腓 骨神経麻瘏によるdrop footなど）を呈して来院 するケースもあります。一般検查で赤沈立進, CRP陽性, 貧血, 白血球増加, 尿異常所見など がみられます。ことに腎機能障害の有無に注意 する必要があります.特異的な検査所見はMPOANCA (myeloperoxidase-antineutrophil cytoplasmic antibody)(Wegener肉芽腫症ではPR3 (protinase-3)-ANCA）が挙げられ，これが高值 例では, 急速な腎機能悪化や, 肺出血に注意し なければなりません。早急な専門医への紹介が 必要です。

その他, 高齢者の発熱ではリウマチ性多発筋 痛症 $(\mathrm{PMR})$ を念頭におかなければなりません. 頸部から肩にかけての痛み, 慰部から大腿部に かけての痛みがあり, 発熱を伴うこともありま す.この疾患が疑われた場合は赤沈，CRPを検 査します(リウマトイド因子は多くで陰性)，炎
症反応が高值の場合がほとんどです．治療は副 腎皮質ステロイド(プレドニゾロンで $10 \mathrm{mg}$ から $20 \mathrm{mg}$ /日)が奏効することが多く, 患者から感謝 されます，我が国では頻度は低いが，欧米では PMRの約 15 から $30 \%$ に側頭動脈炎が合併する と言われており, 浅側頭動脈の触診やMR (magnetic resonance) アンギオグラフィやカラードプ ラ超音波検査で側頭動脈の走行を確認します.

おわりに

リウマチ膠原病の診療では, それぞれの疾患 の発症頻度が高いものではなく, かつ難治性で ありしばしば敬遠されがちですが, プライマリ・ ケア医で対応できることも充分あります。こわ ばりやRaynaud現象を呈する疾患では視診・触診 が大切であること, RAの早期診断の重要性, ま たそれらの疾患の中には特に治療を要しないも のが含まれることがわかったと思います．発熱 に関しては，見逃してはいけない疾患を説明し ました. 今後の日常診療の参考にしてください. 